УДК 346.9

DOI https://doi.org/10.32849/2663-5313/2021.1.12

\title{
Наталія Петренко,
}

канд. юрид. наук,

дочент кафедри професійних та спечіальних дисииплін

Херсонського факультету

Одеського державного університету внутрішніх справ

\section{ЗАСТОСУВАННЯ ПРОЦЕДУРИ ВРЕГУЛЮВАННЯ СПОРУ ЗА УЧАСТЮ СУДДІ В ГОСПОДАРСЬКОМУ СУДОЧИНСТВІ}

Статтю присвячено інституту врегулювання спору за участю судді. Так, норми, які регламентують ию процедуру, запроваджено до Господарського процесуального кодексу Украйни у 2017 році. Проте, незважаючи на те що вони вже діють майже три роки, широкого застосування вони не отримали. Отже, станом на съогодні в судовій системі та суспільстві виникли певні труднощі щодо реалізащії чієї процедури. Убачається, що не здобула прихильності ні серед суддівського корпусу, ні серед адвокатів та було піддана критиці з боку науковиів. Однак зростання кількості спорів, у тому числі тих, які передаються на вирішення суду, відсутність культури ведення ділових переговорів і загалом вирішення конфліктів шляхом ведення переговорів зумовлюють необхідність детального дослідження цвого інституту. Так, однією з найвагоміших проблем, які виявлені при дослідженні цього інституту, є загроза зловживання проиесуальними правами та застосування иього інституту з метою заміни складу суду, який розглядає справу. При иьому науковиі зауважують, що ией інститут буде застосовуватися за відсутності підстав для появи відводу. У статті запропоновано шляхи вирішення окресленої проблеми. Окремою формою зловживання правом при зверненні до иієї процедури $\epsilon$ бажання однієї зі сторін затягнути розгляд справи по суті. Проте з аналізу норм господарського процесуального законодавства вбачається, що наявні дієві механізми, які дають змогу ивого уникнути. Отже, у результаті аналізу чинного законодавства, наукової доктрини та судової практики зроблено висновок щодо необхідності вдосконалення норм господарського проиесуального законодавства з метою підвищення ефективності цього інституту. Отже, процедура врегулювання спору за участю судді має можливість успішно бути інтегрованою в судовий проиес як один із видів альтернативного вирішення спорів.

Ключові слова: урегулювання спору за участю судді, спільні наради, закриті наради, господарське судочинство.

Постановка проблеми. Стан судової системи й процесуального законодавства $€$ показником дотримання демократичного та правового вектору розвитку держави. Але тривала криза судової системи призводить до необхідності її реформування. Так, у результаті чергової реформи та прийняття нових редакцій процесуальних кодексів запровадженні нові процесуальні інституту. Новелою Господарського процесуального кодексу (далі - ГПК) України стало інтегрування інституту врегулювання спору за участю судді в господарське судочинство, який належить до альтернативних способів вирішення спорів.

Урегулювання спору за участю судді мало стати альтернативою вирішення спору судом і дати можливість сторонам самостійно вирішити конфлікт, який виник між ним, керуючись власними інтересами. Проте станом на сьогодні запроваджена новела не стала реальною альтернативою завершенню судового процесу шляхом отримання судового рішення по справі. 3 метою подальшого розвитку цього процесуального інституту необхідно його детальне дослідження та запровадження певних змін, які створять умови для його повноцінного функціонування.

Проблемі врегулювання спору за участю судді приділяли увагу такі науковці, як I. Бутирська, Н. Бондаренко-Зелінська, О.С. Можайкіна, В.С. Прущак та інші.

Метою статті є аналіз результатів запровадження процедури врегулювання спору за участю судді в господарське судочинство через дослідження проблем, які виникли в ході реалізації норм процесуального законодавства, і виявлення шляхів їх вирішення.

Виклад основного матеріалу. Так, розвиток альтернативних способів вирішення 
спорів в Україні має дуже нетривалу історію. Говорячи про історичну ретроспективу, необхідно погодитися з висновком Н. Бондаренко-Зелінської, яка стверджує, що фактично в Україні процес розвитку способів урегулювання спорів, альтернативних судовому, активізувався лише після переорієнтування державотворчих процесів на створення незалежної, демократичної, правової держави (кілька останніх десятиліть) [1, с. 64]. Повертаючись безпосередньо до врегулювання спору за участю судді, убачається, що надання можливості сторонам мирно врегулювати спір, який уже перебуває на розгляді в суді, за безпосередньою за участю судді $€$ інтегруванням одного 3 видів альтернативного врегулювання спору в судову систему.

Проте й у науковій літературі, і серед практиків виникає багато нарікань на недосконалість цієї процедури та наявні в ній недоліки, які фактично унеможливлюють їі ефективне використання в судовій практиці.

Зокрема, одним із найістотніших недоліків, які вбачають у досліджуваній процедурі й науковці, і правники-практики, $€$ можливість застосування процедури врегулювання спору за участю судді з метою зміни складу суду, який розглядає справу. Чинним ГПК України закріплено, що врегулювання спору за участю судді проводиться суддею-доповідачем одноособово незалежно від того, у якому складі розглядається справа (ч. 1 ст. 188 ГПК України). Зокрема, А. Бобкова, досліджуючи перспективи впровадження цієї процедури та вивчаючи ще Проект ГПК України, зробила висновок, що ймовірне також використання зазначеної процедури суддями з метою подальшого перерозподілу справи іншому складу суду й усунення від прийняття рішення у справі (квазісамовідвід від розгляду справи тощо) [2, с. 49]. На думку В. Мамницького та М. Кахнова, указана процедура може бути використана стороною (сторонами) з метою заміни судді в разі відсутності підстав для його відводу [3, с. 117]. Аналогічної точки зору дотримуються Т. Бережна [4, с. 20], А. Михайлов [5, с. 20] та інші. Обговорення цієї проблеми та наявності такої можливості призводить до того, що до сторони, яка пропонує застосувати досліджувану процедуру, у протилежної сторони виникає недовіра, яка обгрунтовується можливою наявністю бажання передати спір на вирішення іншого судді. Отже, ще більше поглиблюється конфлікт між сторонами та зростає рівень недовіри один до одного, що не тільки не призводить до примирення сторін, а й, навпаки, може змінити вектор взаємовідносин від налагодження діалогу до поглиблення суперечностей.

Так, для подолання зазначеної проблеми вбачається за можливе змінити порядок визначення судді, який бере участь у цій примирювальній процедурі. Відповідно до норм чинного ГПК України, суддею, який безпосередньо проводить процедуру врегулювання спору, є суддя по цій самій справі. 3 метою уникнення зазначеної вище проблеми необхідно закріпити, що врегулювання справи за участю судді проводиться іншим суддею, якого буде визначено в порядку, установленому ст. 32 ГПК України. При цьому влучним $€$ зауваження Л. Романадзе, яка зазначає, що для ефективного функціонування досліджуваного інституту суддям необхідно опанувати спеціальні навички [6]. Тобто доцільним є запровадження порядку передачі справи 3 метою врегулювання спору іншому судді, який не приймає участі в розгляді справи (не є головуючим по справі чи членом колегії). При цьому в розподілі мають брати участь лише судді, які пройшли спеціальне навчання та мають відповідні навички проведення такої процедури. Уважаємо, що такі зміни не тільки підвищать довіру до процедури врегулювання спору за участю судді, а й зроблять їі ефективною та корисною для сторін.

Д. Луспеник зараховує до випадків зловживання сторонами правом можливість скористатися зазначеною процедурою, коли одна зі сторін прагне врегулювати спір мирним шляхом, а інша дає згоду на проведення процедури лише з метою затягування розгляду справи [7]. Проте вірогідність існування таких ризиків є незначною та при їх виникненні й суд, і сторони по справі можуть ініціювати припинення цієї процедури. Позитивним прикладом вирішення аналогічної ситуації є ухвала господарського суду Херсонської області від 18 червня 2019 року у справі № 923/279/19. Так, ухвалою у справі від 13 червня 2019 р. розпочато процедуру врегулювання спору за участю судді, яка ініційована відповідачем. Спільна нарада за участю сторін призначена на 12 годину 00 хвилин 14 червня 2019 р. Представник відповідача не прибув на вказану спільну нараду, у зв'язку з чим позивачем 14 червня 2019 р. подано заяву про припинення врегулювання спору за участю судді [8].

Однак у цьому разі необхідно зауважити, що природа досліджуваної процедуру грунтується на добровільності й суддя в цій процедурі виконує роль посередника. Отже, дати спільних і закритих нарад, які проводяться судом, мають бути узгоджені зі сторонами.

У світлі запропонованих змін трансформації зазнає й принцип добровільності 
процедури врегулювання спору за участю судді. Так, станом на сьогодні зазначений принцип поширює свою дію виключно на сторін по справі, які виявили бажання взяти участь у цій процедурі. Суддя, у свою чергу, не може відмовитися проводити цю процедуру та брати в ній участь $[9$, с. 75$]$. У разі обрання судді, який буде виступати посередником між сторонами серед суддів, які пройшли відповідне навчання та виявили бажання брати участь у переговорах сторін, добровільність участі в зазначеній процедурі буде стосуватися й суддю. Проте, на відміну від сторін переговорів, він не зможе добровільно вийти з них.

Отже, принцип добровільності участі в процедурі врегулювання спору за участі судді є двоєдиним. Перше - він включає добровільність участі в процедурі безпосередньо сторін по справі - позивача та відповідача. Зокрема, вона полягає в їхній активній позиції та виявленні наміру вирішити спір мирно, шляхом погодження участі в ній. Друге - це добровільність участі в процедурі судді, яка буде виражатися в їхній участі в автоматичному розподілі, до якого будуть включені судді які пройшли відповідне навчання, отримали навички ведення переговорів і виявили бажання брати участь у процедурі врегулювання спорів за участю судді.

Зміна механізму визначення судді-перемовника і трансформація змісту принципу добровільності буде мати ще один позитивний наслідок, окрім підвищення довіри до досліджуваної процедури, у зв'язку з відсутністю навичок ведення переговорів як посередника, нерозумінням природи примирювальних процедур, укоріненням у суспільстві та самій судовій системі ролі судді як носія однієї гілок державної влади, який одноособово приймає рішення по справі виключно в межах чинного законодавства та за власним переконанням.

\section{Висновки}

На підставі вищевикладеного можна зробити висновок, що процедура врегулювання спору за участю судді інтегрована в національне законодавства в ході реформування судової системи та має на меті надання сторонам конфлікту самостійно, керуючись влас- ними інтересами, вирішити спір. Проте в ході реалізації цієї процедури виникли труднощі, зумовлені їі недосконалістю, що, у свою чергу, зумовило поглиблення недовіри до цього альтернативного способу вирішення конфліктів. 3 метою подолання виявленого недоліку пропонується змінити процедуру визначення судді, який буде брати участь у переговорах між сторонами, а саме передавати спір для його врегулювання іншому судді, який буде мати спеціальні навички ведення перемовин.

\section{Список використаних джерел:}

1. Бондаренко-Зелінська Н.Л. Врегулювання спору за участю судді: проблеми та перспективи застосування. Університетські наукові записки. 2018, № 67-68. C. 62-70.

2. Бобкова А. Новели проекту Господарського процесуального кодексу України. Право України. 2017. № 9. С. 45-50.

3. Мамницький, В.Ю., Кахнова, М.Г. Врегулювання спору за участю судді: проблемні аспекти правозастосовчої практики. Журнал східноєвропейського права. 2019. № 64. С. 112-123.

4. Бережна Т. Процесуальне хуліганство та адвокатська творчість: де межа? Юридична газета. 2018. № 32-33 (634-635). С. 20.

5. Михайлов О.М. Процесуальна диверсія VS врегулювання спору за участю судді, 2018. C. 37-41. URL: http://dspace.onua.edu.ua/ bitstream/handle/11300/10961/Mykhailov\%20 $\mathrm{O} \% 20 \mathrm{M}$.pdf?sequence $=1$.

6. Романадзе Л.Д. Врегулювання спору за участю судді та інші процесуальні новели: вплив на розвиток медіації. URL: http://mediation. ua/wpcontent/uploads/2017/05/Stattya-proMediatsiyu-v-proektah-protses-kodeksiv-2.pdf.

7. Луспеник Д. Новелізація цивільного процесу позитивно вплинула на судову практику. Судебно-юридическая газета. 2018. URL: https:// sud.ua/ru/news/publication/125882-novelizatsiyatsivilnogo-protsesupozitivno-vplinula-na-sudovupraktiku-f6c2df.

8. Ухвала господарського суду Херсонської області від 18 червня 2019 року у справі № 923/279/19. URL: https://reyestr.court.gov.ua/ Review/82460925.

9. Петренко Н.О. Врегулювання спору за участі судді в господарському судочинстві. Підприємничтво, господарство $i$ право. 2018. № 10. C. $73-77$.

Nataliia Petrenko. Application of the dispute resolution procedure with the participation of a judge in economic litigation

The article is devoted to the institute of dispute settlement with the participation of a judge. Thus, the norms regulating this procedure were introduced in the Commercial Procedural Code of Ukraine in 2017. However, despite the fact that they have been in force for almost three years, they have not been widely used. Thus, as of today, the judicial system and society have encountered certain difficulties in implementing this procedure. It seems that it has not received affection either among the judiciary or among lawyers and has been criticized by scholars. However, the growth of the number of disputes, including those referred to the court, 
the lack of a culture of business negotiations and in general the resolution of conflicts by negotiation make it necessary to study this institution in detail. Thus, one of the important problems that were revealed in the study of this institute is the threat of abuse of procedural rights and application of this institute in order to replace the composition of the court considering the case. At the same time, scholars note that this institution will be applied in the absence of grounds for recusal. The article proposes ways to solve the indicated problem. A separate form of abuse of the right of recourse to this procedure is the desire of one of the parties to delay consideration of the case on the merits. However, according to the analysis of the norms of economic procedural legislation, there are effective mechanisms that allow avoiding this. So as a result of the analysis of the current legislation, scientific doctrine and judicial practice the conclusion is made about the need to improve the norms of economic procedural legislation in order to increase the effectiveness of this institution. Thus, the procedure for settling a dispute with the participation of a judge has the possibility to be successfully integrated into the judicial process, as one of the types of alternative dispute resolution.

Key words: settlement of a dispute with the participation of a judge, joint meetings, closed meetings, economic litigation. 